\title{
Distillery industrial wastewater(DIW) treatment by the combination of sono(US), photo(UV) and electrocoagulation(EC) process
}

Perumal Asaithambi ( $\sim$ drasaithambi2014@gmail.com )

Jimma University College of Engineering and Technology: Jimma University Institute of Technology https://orcid.org/0000-0002-0533-0178

\section{Rajendran Govindarajan}

Hindustan Institute of Technology and Science: Hindustan University

\section{Research Article}

Keywords: Distillery industrial wastewater, Sono-Photo-Electrocoagulation, COD removal, color removal, electrical energy consumption, synergy index

Posted Date: March 1st, 2022

DOI: https://doi.org/10.21203/rs.3.rs-1330571/v1

License: (c) (1) This work is licensed under a Creative Commons Attribution 4.0 International License. Read Full License 
Distillery industrial wastewater(DIW) treatment by the combination of sono(US), photo(UV) and electrocoagulation(EC) process

${ }^{\mathrm{a}}$ Faculty of Civil and Environmental Engineering,

${ }^{\mathrm{b}}$ Department of Chemical Engineering,

Hindustan Institute of Technology and Science, Rajiv Gandhi Salai, Padur, Chennai - 603103, Tamilnadu, India.

*Corresponding author: Tel.: +251-472115547; Fax.: +251-471111450 
The color and Chemical Oxygen Demand (COD) reduction in distillery industrial effluent (DIW) was investigated utilizing photo (UV), sono (US), electrocoagulation (EC), UV+US, $27 \mathrm{UV}+\mathrm{EC}, \mathrm{US}+\mathrm{EC}$, and $\mathrm{US}+\mathrm{UV}+\mathrm{EC}$ technologies. The empirical study demonstrated that the UV+US+EC process removed almost $100 \%$ of color and $95.63 \%$ of COD from DIW while

29 consuming around $6.97 \mathrm{kWh} \mathrm{m}^{-3}$ of electrical energy at the current density of $0.175 \mathrm{~A} \mathrm{dm}^{-2}$, COD of $3600 \mathrm{mg} \mathrm{L}^{-1}$, UV power of $32 \mathrm{~W}$, US power of $100 \mathrm{~W}$, electrode pairings of $\mathrm{Fe} / \mathrm{Fe}$, interelectrode distance of $0.75 \mathrm{~cm}, \mathrm{pH}$ of 7 , and reaction time of $4 \mathrm{~h}$, respectively. The values found were much greater than those produced using UV, US, EC, UV+US, UV+EC, and US+EC methods. The influence of various control variables such as treatment time $(1-5 \mathrm{~h})$, current density $\left(0.075-2.0 \mathrm{~A} \mathrm{dm}^{-2}\right)$, COD $\left(1800-6000 \mathrm{mg} \mathrm{L}^{-1}\right)$, inter-electrode distance $(0.75-3.0 \mathrm{~cm})$, electrode pairings $(\mathrm{Fe} / \mathrm{Fe}, \mathrm{Fe} / \mathrm{Al}, \mathrm{Al} / \mathrm{Fe}, \mathrm{Al} / \mathrm{Al}), \mathrm{UV}(8-32 \mathrm{~W})$, and $\mathrm{US}(20-100 \mathrm{~W})$ on the color and COD reduction were investigated to determine the optimum operating conditions. It was observed that, an increase in treatment time, current density, UV and US power, decrease in the COD, and interelectrode distance with $\mathrm{Fe} / \mathrm{Fe}$ electrode combination improved the COD removal efficiency. The UV and US+EC processes' synergy index was investigated and reported. The results showed that, the US+UV+EC treatment combination was effective in treating industrial effluent and wastewater.

Keywords: Distillery industrial wastewater; Sono-Photo-Electrocoagulation; COD removal; color removal; electrical energy consumption; synergy index. 


\section{Introduction}

Numerous organizations have shifted their focus in recent years toward non-chemical treatments that are more sustainable, such as electrochemistry treatment technology, due to its advantages over conventional chemical treatments. Electrocoagulation (EC) is one such example of this technology, which is employed in place of conventional physical-chemical processes (Deghles and Kurt 2016; Cotillas et al. 2020). This cutting-edge treatment approach often provides superior benefits to conventional chemical coagulation systems without the associated costs and adverse effects (Deghles and Kurt 2016).

The EC process has gained recognition as a viable and successful method of treating effluent and wastewater from a wide variety of industries (Nigri et al. 2020; Preethi et al. 2020; Chezeau et al. 2020; Moussavi et al. 2021). The EC has the ability to remove and decrease undesirable contaminants/pollutants from a variety of sources, including wastewater and industrial effluents (Nigri et al. 2020). Such contaminants/pollutants include suspended and dissolved solids, pathogens, organic and inorganic chemicals, etc (Romani et al. 2020). EC units are not complicated to install and do not require a large amount of material, and chemical addition are simple to operate, require a short startup period, are easy to control, have a high capacity for pollutant removal, facilitate the collection of produced sludge, and are relatively inexpensive and easy to acquire (Raschitor et al. 2014; Deghles and Kurt 2016). The electrodes that are frequently utilized in an EC system are constructed of iron (Fe) or aluminum (Al), both of which are readily available (Chen et al. 2020; Chezeau et al. 2020; Li et al. 2021).

The primary disadvantages of the EC process are the high anode consumption, electrode passivation on the cathode which results in reduction of current, and process and pollutant removal efficiency, and increased electrical energy consumption (EEC) (Al-Qodah et al. 2020). 
Additionally, if not properly managed, the generated sludge may contain a variety of components,

71 including potentially dangerous compounds to the environment (Romani et al. 2020). The EC

72 technology as a stand-alone treatment process may have significant practical constraints,

73 particularly if the wastewater is extremely polluted/contaminated (Aziz et al. 2016). Hence, an

74 efficient and relatively inexpensive treatment techniques are required. In response to this, various

75 studies have demonstrated, combining EC with other treatment methods such as advanced 76 oxidation processes (AOPs) improve its performance.

77 Numerous research studies have demonstrated that EC works cohesively with other 78 treatment modalities, including ozone $\left(\mathrm{O}_{3}\right)$ assisted EC (He et al. 2007; Das et al. 2021; Mehralian

79 et al. 2021), EC/Adsorption, EC/Chemical coagulation, EC/Magnetic field, EC/reverse osmosis 80 (Al-Qodah et al. 2020), US-EC (Emerick et al. 2020; Moradi et al. 2021), alternating current EC 81 (Alimohammadi et al. 2019; Payami Shabestar et al. 2021), peroxi-EC (Sandhwar and Prasad 82 2018), photo-EC (Farhadi et al. 2012; Asaithambi et al. 2016; Moradi and Moussavi 2019), aerated 83 EC (Akansha et al. 2020), EC-nanofiltration and membrane filtration (Tavangar et al. 2019; 84 Gönder et al. 2020; Ucevli and Kaya 2021) for the elimination of contaminants from industrial 85 effluent and wastewater.

Farhadi et al. (2012) compared the various processes for removal of COD from 87 pharmaceutical wastewater. Their findings show that the following order of COD removal 88 efficiency was established under optimal operating conditions for each process: peroxi-EC 89 >peroxi-photo-EC > photo- EC > EC. Cotillas et al. (2014) reported that, when UV irradiation and 90 electrocoagulation (UV-EC) were utilized at low current densities, a synergistic effect was shown 91 for the reduction of turbidity and disinfection rate. Additionally, they observed that performance 92 improves when UV radiation is used to promote the creation of hydroxyl and chlorine radicals. 
Jallouli et al. (2020) showed that the sequential EC and UV treatment processes were effective at

94 reducing COD in tannery effluent, and their results indicated that the combined procedure reduced

95 COD by $94.1 \%$, compared to $85.7 \%$ and $55.9 \%$ for the individual EC and UV treatments

96 respectively.

97 According to Özyonar et al. (2020) the removal of color and COD from aqueous dye 98 solutions by US+EC process was significantly more than by US or EC alone. Additionally, they 99 discovered that when US irradiation was combined with EC treatment, electrode passivation was 100 greatly reduced compared to the EC method. In a more recent study by Prajapati, (2021) performed 101 a performance and cost analysis on the removal of COD and color from BDE using US, EC, and 102 US+EC. Their findings indicated that when compared to US and EC alone, the US+EC process 103 had much greater COD $(99.1 \%)$ and color $(61.6 \%)$ removal efficiencies with a $0.58 \mathrm{kWh} \mathrm{m}^{-3}$ 104 energy consumption. Emerick et al. (2020) established that the ECF and ECF/US procedures are 105 viable options for wastewater treatment. Oza et al. (2021) demonstrated that integrating US and 106 EC was an effective treatment method for the removal of hazardous contaminants such as arsenic. Our meticulous analysis of the literature established that hybrid approaches based on 108 electrochemical and AOPs were effective at removing contaminants from synthetic wastewater 109 (Zazou et al. 2019; Chanikya et al. 2021). Meanwhile, only a few studies have focused on real 110 wastewater and industrial effluent utilizing hybrid electrochemical and AOPs (Valero et al. 2017; 111 da Costa et al. 2019). Additionally, apart from the removal of contaminants from industrial effluent 112 and wastewater, the hybrid process's EEC is critical from an economic standpoint. Moreover, 113 environmental engineers must create and develop simple, efficient, and cost-effective hybrid 114 procedures that address the shortcomings of conventional treatment systems. 
UV and US with an EC procedure for determining the EEC associated with the color and COD

117 reduction from DIW. The purpose of this investigation was to create and develop novel treatment

118 strategies for determining EEC while removing contaminants from DIW. The main objective of

119 this work is to compare UV, US, EC, UV+US, UV+EC, US+EC, and US+UV+EC processes in

120 terms of color and COD reduction, as well as to determine the EEC from DIW and to choose the

121 best one. The effect of process parameters such as treatment time (1-5 h), current density $(0.075-$

$\left.1222.0 \mathrm{~A} \mathrm{dm}^{-2}\right), \mathrm{COD}\left(1800-6000 \mathrm{mg} \mathrm{L}^{-1}\right)$, inter-electrode distance $(0.75-3.0 \mathrm{~cm})$, combination

123 electrode (Fe/Fe, Fe/Al, Al/Fe, Al/Al), UV (8-32 W), and US (20-100 W) on the COD removal

124 and EEC of DIW treated with a UV+US+EC process was investigated. Additionally, the synergy

125 index between UV and US/EC procedures was evaluated and reported.

\section{2. Material and methods}

\section{$127 \quad 2.1$ Wastewater characterization}

The DIW used in this investigation was obtained from distilleries in Erode, Tamil Nadu,

129 India. The grab sampling technique was employed for sampling. To ensure against any degradation

130 in wastewater quality, the effluent was preserved in a cold room $\left(+4{ }^{\circ} \mathrm{C}\right)$. The DIW was

131 characterized using standard procedures. The DIW had the odor of burnt sugar, a dark brown color,

132 a pH of 4.1-4.3, a Biochemical Oxygen Demand (BOD) of 7000-8000 mg L ${ }^{-1}$, a Chemical Oxygen

133 Demand (COD) of 80,000-90,000 mg L ${ }^{-1}$, a Total Dissolved Solids (TDS) of 5550-5750 $\mathrm{mg} \mathrm{L}^{-1}$, 134 and a Total Suspended Solids (TSS) of $15.44 \mathrm{~g} \mathrm{~L}^{-1}$.

135 The chemicals used in the experiments were $\mathrm{H}_{2} \mathrm{SO}_{4}, \mathrm{NaOH}, \mathrm{K}_{2} \mathrm{Cr}_{2} \mathrm{O}_{7}, \mathrm{Na}_{2} \mathrm{~S}_{2} \mathrm{O}_{3}$, $136\left(\mathrm{NH}_{4}\right)_{2} \mathrm{Fe}\left(\mathrm{SO}_{4}\right)_{2}$, etc. Merck, India supplied the analytical reagent $(\mathrm{AR})$ grade chemicals and the 137 chemicals were utilized in their original state without further purification. 


\subsubsection{Electrocoagulation (EC)}

For the treatment of DIW, the experimental setup scheme for the integrated US+UV+EC is depicted in Fig. 1(a), (b) \& (c). The US, UV, and EC process units were used in the integrated process. The EC (Fig. 1(a)) was carried out in a batch electrochemical reactor composed of an acrylic sheet with a 2.5 L capacity. Each experiment was run with a 2.0 L DIW operational capacity. The anode/cathode electrodes were made of $\mathrm{Fe} / \mathrm{Fe}, \mathrm{Al} / \mathrm{Al}, \mathrm{Fe} / \mathrm{Al}$, and $\mathrm{Al} / \mathrm{Fe}$. Both electrodes had the same dimensions with $0.1 \mathrm{~cm}$ thickness and had an effective electrode surface area of $10 \mathrm{~cm} \times 15 \mathrm{~cm}$ (width $\mathrm{x}$ height). The anodes and cathodes were coupled in parallel to a direct current (DC) power supply (APLAB Ltd; Model L1606). Before each experiment, the electrodes used in the processes were manually cleaned with a $35 \% \mathrm{HCl}$ solution, washed with distilled water, and dried. Using a $\mathrm{pH}$ meter, the $\mathrm{pH}$ of effluent was measured and corrected with $\mathrm{H}_{2} \mathrm{SO}_{4}$ and $\mathrm{NaOH}$ solution (Elico: Model LI120). Using the direct current (DC) power source, a continuous DC was supplied across the electrodes when the required experimental condition was achieved.

\subsubsection{Sono-Electrocoagulation $(U S+E C)$}

Before beginning the ultrasonication process, the bath (Elma Ultrasonics type d-7822 K) was filled with distilled water to the recommended level. The ultrasonic water bath's distilled water was refilled before each experiment began. The EC reactor system was submerged in ultrasonic water bath to begin the US+EC process (Fig.1 (b)).

\subsubsection{Sono-Photo-Electrocoagulation $(U S+U V+E C)$}

The operating conditions for the experiment were similar to those for the US+EC process, but the reaction contents were further exposed to UV irradiation. As a UV light source, an 8-32 
161 Watts low-pressure mercury lamp emitting primarily at $254 \mathrm{~nm}$ was used. Due to the fact that the

162 UV lamp was incorporated into the US+EC process, the procedure is referred to as US+UV+EC

163 (Fig.1 (c)). Throughout the EC, US+EC, and US+UV+EC processes, the cell voltage and current

164 are monitored using a multimeter. Regularly timed samples were collected from the reactor and

165 added to an Erlenmeyer flask holding $\mathrm{Na}_{2} \mathrm{~S}_{2} \mathrm{O}_{3}$ solution to quench the process. After centrifuging

166 the samples at 10,000 rpm for 15 minutes to separate the solid particles and liquid, the supernatant

167 liquid is immediately analyzed for COD (Spectroquant $®$ TR320) and colour (Spectroquant Pharo

168 ®300).

1692.3 Analysis

$170 \quad$ 2.3.1 Color and COD removal efficiency, (\%)

171 The color and COD reduction efficiencies were determined using the following equations (1) and 172 (2).

173 The color was determined using a UV/Vis spectrophotometer at the wavelength 174 corresponding to the maximal absorbance $\lambda_{\max }(300 \mathrm{~nm})($ Spectroquant Pharo $® 300)$.

$175 \%$, color removal $=\left(\frac{A b s_{i}-A b s_{t}}{A b s_{i}}\right) * 100$

176 Where, $A b s_{i}$ and $A b s_{t}$ are the absorbances of the DIW at the corresponding wavelength $\left(\lambda_{\max }\right)$ before 177 and after the treatment process.

$178 \%$, COD removal $=\left(\frac{C_{O D}-C O D_{t}}{\operatorname{COD}_{i}}\right) * 100$

179 Where, $C O D_{i}$ and $C O D_{t}$ are the $\operatorname{COD}\left(\mathrm{mg} \mathrm{L}^{-1}\right)$ of DIW prior to and following the after treatment, 180 respectively.

\subsubsection{Electrical energy consumption (EEC)}

The removal efficiency of color and COD along with EEC is evaluated for the comparison of UV, US, EC, UV+US, UV+EC, US+EC, and US+UV+EC process to DIW. The EEC-kWh ${ }^{-}$ 
$184^{3}$ ) of UV, US, and EC primarily dominated the treatment cost of the integrated system. The 185 equation was listed as follows.

$186 E E C_{U V / U S / E C}=E E C_{U V}++E E C_{U S}+E E C_{E C}$

187 Where, $E E C_{U V / U S / E C}, E E C_{U V}, E E C_{U S}$ and $E E C_{E C}$ are electrical energy consumption for

$188 \mathrm{UV}+\mathrm{US}+\mathrm{EC}, \mathrm{UV}, \mathrm{US}$ and EC process.

$189 \quad$ 2.3.3 Electrocoagulation (EC)

$190 \quad E E C_{E C}=\frac{U x I x t}{V_{R}},\left(k W h r m^{-3}\right)$

191 Where, $U$ represents the cell voltage (V), $I$ represent the current (A), $t$ represents the 192 reaction time (h) and $V_{R}$ represents the volume of DIW utilized.

193 2.3.4 Photo (UV) and Sonication (US)

$194 E E C_{U V}+E E C_{U S}=\frac{P_{e t} \times t \times 1000}{V_{R} \times 60 \times \log \left(\frac{C O D_{t}}{C O D_{i}}\right)},\left(k W h m^{-3}\right)$

Where, $P_{e l}$ denotes the rated power in $\mathrm{kW}(0.008,0.016$, and $0.032 \mathrm{~kW}$ for UV and 0.02 ,

$1960.04,0.06,0.08$ and $0.100 \mathrm{~kW}$ for sonication).

197 3. Results and discussion

$198 \quad 3.1$ Studies on operating parameters

199 3.1.1 Optimization of $U S+U V+E C$ process

200 To optimize the US+UV+EC process performance, the impacts of treatment time, current 201 density, COD, UV and US power, electrode combination, and inter-electrode distance were 202 explored and addressed in detail below.

203 3.1.1.1 Treatment time

One of the most essential factors for industrial wastewater treatment employing hybrid 205 procedures is the effect of treatment time (Maha Lakshmi and Sivashanmugam 2013). The 
206 influence of reaction time on removal of COD and EEC from DIW using US+UV+EC process

207 with the current density of $0.75 \mathrm{~A} \mathrm{dm}^{-2}$, inter-electrode distance of $0.75 \mathrm{~cm}$, COD of $3600 \mathrm{mg} \mathrm{L}^{-}$

$20{ }^{1}, \mathrm{pH}$ of 7, electrode pairing of Fe/Fe, UV of $32 \mathrm{~W}$ and $\mathrm{US}$ of $100 \mathrm{~W}$ the results are depicted in the

209 Fig. 2. The Fig. 2 indicates that, the \% COD removal and EEC has increased with an increase in

210 treatment time. The COD removed is proportional to the concentration of ions generated by the

211 electrodes. When the treatment time increases, a constant amount of electrodes ions and their

212 oxidizing species are produced. Consequently, an increase in the treatment time increases the COD

213 removal efficiency. Increased EEC via cell voltage results in an increase in hydroxyl radicals,

214 which improves the COD removal.

215 3.1.1.2 Current density

216 The current density is an important factor in the hybrid EC process for the treatment of 217 industrial effluent (Sandhwar and Prasad 2018; Mehralian et al. 2021; Moradi et al. 2021). The 218 current density was varied between 0.07 and $0.20 \mathrm{~A} \mathrm{dm}^{-2}$ in this investigation for the US+UV+EC 219 system utilizing the DIW, and the findings are depicted in Fig. 3. As illustrated in Fig. 3, the EEC 220 of the hybrid US+UV+EC process has increased from 3.11 to $7.01 \mathrm{kWh} \mathrm{m}^{-3}$ and the COD removal 221 efficiency has increased from 37.84 to $95.63 \%$ for an increase in current density from 0.07 to 0.175

$222 \mathrm{~A} \mathrm{dm}^{-2}$ at constant treatment time of $4 \mathrm{~h}$. According to Faraday's rule, the quantity of Fe dissolved 223 by electrochemical reaction is proportionate to the charge loadings on the surface of electrode that 224 promote flocculation process (Dizge et al. 2018). Generally, increasing current density results in 225 an increase in coagulant formation with anode dissolution and $\mathrm{H}_{2}$ gas production via water 226 reduction at the cathode (Farhadi et al. 2012). Enormous amounts of coagulants increase the 227 efficacy of COD removal via the adsorption and precipitation processes. Additionally, $\mathrm{H}_{2}$ gas 228 coalesces the lighter particles, resulting in an increase in the COD removal efficiency of pollutants 
229 via the flotation process (Nawarkar and Salkar 2019; Negarestani et al. 2020). Additionally, as

230 illustrated in Fig. 3, after increasing the current density from 0.175 to $0.200 \mathrm{~A} \mathrm{dm}^{-2}$, EEC increased

231 from 7.01 to $8.89 \mathrm{kWh} \mathrm{m}^{-3}$, but COD removal efficiency declined from 95.63 to $91.60 \%$. This

232 might account for the production of necessary coagulants at a current density of $0.175 \mathrm{~A} \mathrm{dm}^{-2}$, and

233 hence current density of $0.175 \mathrm{~A} \mathrm{dm}^{-2}$ are considered to be the optimum values for a $3,600 \mathrm{mg} \mathrm{L}^{-}$

$234{ }^{1}$ concentration of DIW.

235 According to Fig. 3, the overall EEC increased from 3.11 to $8.89 \mathrm{kWh} \mathrm{m}^{-3}$ with an increase

236 in current density from 0.075 to $0.20 \mathrm{~A} \mathrm{dm}^{-2}$. This could be because current density is directly

237 related to cell voltage (Dizge et al. 2018).

238 3.1.1.3. COD

239 For wastewater and industrial effluent treatment, the initial pollutant concentration

240 influences the hybrid EC process (Moradi et al. 2021). The US+UV+EC process was evaluated

241 for its efficiency in removing COD and EEC from DIW by adjusting the initial COD concentration

242 from 1,800 to $6,000 \mathrm{mg} \mathrm{L}^{-1}$, as shown in Fig. 4. The COD removal efficiency of 100\%, 95.63\%,

$24379.84 \%, 63.04 \%$, and 49.60\% were reached with initial COD concentrations of 1800, 3600, 4400,

244 5200, and $6000 \mathrm{mg} \mathrm{L}^{-1}$, respectively. As the initial COD concentration raised from 1800 to 6000

$245 \mathrm{mg} \mathrm{L} \mathrm{L}^{-1}$, the EEC and COD removal rate dropped; hence, a longer time was required to attain a

246 constant COD removal efficiency during the treatment process. This is because consistent current

247 density and treatment time create the same amount of metal hydroxide (Moradi et al. 2021). This

248 quantity is insufficient to coagulate and flocculate the polluted waters with increased COD

249 concentration (Ahlawat et al. 2008). As a result, the amount of $\mathrm{Fe}(\mathrm{OH})_{3}$ coagulant produced is

250 insufficient for sedimentation as the COD concentration increases. Excessive surface oxidation 
251 reduces anode electrode's ability to release metal ions and generate hydroxyl radicals (Moradi et

252 al. 2021). As a result, the efficiency with which COD is removed decreases.

253

254

255

256

257

258

259

260

261

262

263 electrical energy usage in the US+UV+EC process for DIW.

264 3.1.1.5. US power

265

266

267

268

269

270

271

272 efficiency of the US+UV+EC process. As a result, the ultrasonic procedure effectively eliminates

273 the passive coating, resulting in increased coagulant metal release (He et al. 2016). Li et al. (2013) 
274 observed similar results for the phosphate removal efficiency by comparing the US, EC processes

275 individually and in combinations. They found that the combined US+EC system had a greater

276 phosphate removal efficiency than the efficiency of EC and US individual systems added together.

277 This demonstrates the synergistic effect of integrating the US and EC process.

$278 \quad$ 3.1.1.6. Electrode combination/pairing

279 The electrode material selected is one of the EC control parameters that affects not only

280 the process's performance and efficiency, but also its running cost (Moradi et al. 2021). In a hybrid

281 system, the nature and extent of electrodes have a significant impact on the treatment system's

282 capacity and the pace at which pollutants are eliminated. Due to their availability, low cost, and

283 capacity to generate stable hydroxyl species, Fe and Al electrodes have been utilized more

284 frequently than other electrodes for the elimination of contaminants from wastewater (Igwegbe et 285 al. 2021).

The influence of electrode types on COD removal and EEC was investigated using two 287 anode and cathode materials, Fe and Al, under constant experimental conditions, including current 288 density $-0.175 \mathrm{~A} \mathrm{dm}^{-2}$, initial $\mathrm{pH}-7, \mathrm{COD}-3,600 \mathrm{mg} \mathrm{L}^{-1}$, electrode distance $-0.75 \mathrm{~cm}$, UV $28932 \mathrm{~W}, \mathrm{US}-100 \mathrm{~W}$, and reaction time $-4 \mathrm{~h}$ for DIW using the US+UV+EC process. As illustrated 290 in Fig. 7, using Fe/Fe led in a higher elimination of COD than using Fe/Al, Al/Fe, or $\mathrm{Al} / \mathrm{Al}$. 291 Because the anode and cathode electrodes are the primary components of the hybrid US+UV+EC 292 process, the kind of electrode materials and their component composition had an effect on the 293 hybrid system's performance. The Fe electrode's oxidation potential $(-0.447 \mathrm{~V})$ is significantly 294 greater than the Al electrode's $(-1.662 \mathrm{~V})$, resulting in three times the amount of Fe coagulant 295 produced during contaminant removal. (Asaithambi et al. 2012; Igwegbe et al. 2021). The main 296 rationale is that particles created by $\mathrm{Fe}(\mathrm{OH})_{3}$ may have a higher settling ability than those formed 
297 by $\mathrm{Al}(\mathrm{OH})_{3}$ (Igwegbe et al. 2021). For these reasons, we used Fe electrodes as the anode and 298 cathode for our subsequent studies utilizing the US+UV+EC method for DIW.

\subsubsection{Inter-electrode distance}

To achieve total pollutant removal while lowering operating costs in a hybrid EC process, et al. 2021). The influence of inter-electrode spacing on the US+UV+EC process was investigated using values ranging from 0.75 to $3 \mathrm{~cm}$ under the following operating conditions: current density - $0.75 \mathrm{~A} \mathrm{dm}^{-2}, \mathrm{pH}-7, \mathrm{COD}-3,600 \mathrm{mg} \mathrm{L}-1$, electrode pairing $-\mathrm{Fe} / \mathrm{Fe}, \mathrm{UV}-32 \mathrm{~W}, \mathrm{US}-100 \mathrm{~W}$, and reaction time $-4 \mathrm{~h}$. As shown in Fig. 8, increasing the electrode spacing from 0.75 to $3 \mathrm{~cm}$ lowered the \% COD removal efficiency from 95.63 to $66.40 \%$ and increased EEC from 6.97 to $16.56 \mathrm{kWh} \mathrm{m}^{-3}$. With increasing inter-electrode distance, ohmic losses associated with anode and cathode over voltages and mass transfer resistance increase, inhibiting anodic oxidation and resulting in a decrease in the amount of $\mathrm{Fe}^{2+}$ at the anode (Dalvand et al. 2011). As a result, the production of coagulants in the middle will be slowed down, as would the adsorption of pollutants

311 at a greater inter-electrode distance (Dalvand et al. 2011). Whereas, when the inter-electrode 312 distance is kept to a minimum, the reduced resistance of current flow in solution facilitates the 313 electrolytic process, increasing the percent COD elimination. Therefore, the selection of the 314 optimal inter-electrode distance is $0.75 \mathrm{~cm}$ to minimize EEC while still increase COD removal 315 efficiency.

\subsection{Comparison of electrochemical and AOPs}

The color and COD removal by UV, US, EC, UV+US, UV+EC, US+EC, and US+UV+EC density $-0.75 \mathrm{~A} \mathrm{dm}^{-2}$, inter-electrode distance $-0.75 \mathrm{~cm}, \mathrm{COD}-3600 \mathrm{mg} \mathrm{L}^{-1}, \mathrm{pH}-7$, electrode 
320 pairing of $\mathrm{Fe} / \mathrm{Fe}, \mathrm{UV}-32 \mathrm{~W}, \mathrm{US}-100 \mathrm{~W}$, and reaction time -4 h. As illustrated in Fig. 9 (a),

321 sole process of UV (21.94\% and $12.64 \%)$, sole process of US (26.5\% and 16\%), and hybrid

322 UV+US process (37.20\% and $27.76 \%$ ) were inefficient at removing \% color and \% COD.

323 Additionally, there was a significant level of electrical energy use. The UV, US, and UV+US

324 treatments were unable to create enough free radicals to remove color and COD from the

325 DIW(Farhadi et al. 2012; Dizge et al. 2018; Moradi and Moussavi 2019; Moradi et al. 2021).

326 Additionally, a substantial color removal of $62.55 \%$ and a COD reduction of $50.27 \%$ for EC were

327 accomplished. The color and COD removal by combining UV and US with EC, such as UV+EC,

$328 \mathrm{US}+\mathrm{EC}$, and US+UV+EC hybrid processes, was around 72.45\%, 84.57\%, and 100\%; 60.68\%,

$32971.44 \%$, and $95.63 \%$, respectively. As expected, the hybrid US+UV+EC process outperformed the

330 UV, US, EC, and their combination methods in aspects of removal efficiency of color and COD.

331 This could be because parallel pathways for the generation of sufficient ${ }^{\circ} \mathrm{OH}$ radicals via UV, US,

332 and EC processes have been devised to enable efficient color and COD removal from DIW (Dizge

333 et al. 2018; Moradi and Moussavi 2019; Moradi et al. 2021).

334 During the EC step of the UV+EC process, supplemental UV irradiation was performed.

335 The abundance of photoactive sites had a beneficial influence on the EC process. This

336 improvement was achieved by increasing the rate of synthesis of ${ }^{\circ} \mathrm{OH}$ from $\mathrm{Fe}(\mathrm{OH})^{2+}$

337 photoreduction and photodecomposition of complexes formed during $\mathrm{Fe}^{3+}$ reactions (Aziz et al. 338 2016):

339

$\mathrm{Fe}(\mathrm{OH})^{2+}+h v \rightarrow \mathrm{Fe}^{2+}+{ }^{\bullet} \mathrm{OH}$

340

$R\left(\mathrm{CO}_{2}\right)-\mathrm{Fe}^{3+}+h v \rightarrow R\left({ }^{\bullet} \mathrm{CO}_{2}\right)-\mathrm{Fe}(\mathrm{II}) \rightarrow^{\bullet} \mathrm{R}+\mathrm{CO}_{2}$ 
342

$344 \mathrm{nCO}_{2}+\mathrm{nH}_{2} \mathrm{O}$

\section{Conclusions}

process (Prajapati 2021):

$$
\text { Contaminants }+\mathrm{H}_{2} \mathrm{O}_{2}+\bullet \mathrm{OH}+\text { Ultrasonic irradiation } \rightarrow \text { Intermediates } \rightarrow
$$

The combination of UV and US with EC for the removal of color and COD from DIW is primarily concerned with the consumption of electrical energy in order to establish the economic viability of the hybrid process. The hybrid process's total EEC was calculated using equation (3), and the results are shown in Fig. 9(b). As illustrated in Fig. 9(b), the hybrid UV+US+EC process removed $100 \%$ of color and $95.63 \%$ of COD while consuming $6.97 \mathrm{kWh} \mathrm{m}^{-3}$ of electrical energy for the DIW. The single processes such as EC, UV, US and combinations such as UV+US, $\mathrm{UV}+\mathrm{EC}$, US+EC required significantly more electrical energy to remove the color and COD than the US+UV+EC process. Consequently, the hybrid UV+EC approach can be utilized to remove contaminants from practically any type of wastewater or industrial effluent, regardless of the source of the contaminants.

The purpose of this research was to assess the effectiveness of UV and US combined with EC such as UV, US, EC, UV+US, UV+EC, US+EC, and US+UV+EC processes on the removal of color and COD, as well as the EEC from DIW. When compared to the separate and combined processes, the hybrid US+UV+EC method greatly boosted the color (100\%) and COD (95.63\%) elimination while using less electrical energy $\left(6.97 \mathrm{kWh} \mathrm{m}^{-3}\right)$. To determine the US+UV+EC process performance, controlling variables including treatment time $(1-5 \mathrm{~h})$, current density (0.075-2.0 A dm $\left.{ }^{-2}\right)$, COD (1800-6000 mg L $\left.{ }^{-1}\right)$, UV (8-32 W) and US power (20-100 W), electrode pairings (Al/Al, $\mathrm{Al} / \mathrm{Fe}, \mathrm{Fe} / \mathrm{Al}, \mathrm{Fe} / \mathrm{Fe})$, and inter-electrode distance $(0.75-3.0 \mathrm{~cm})$ were 
364 evaluated and reported. The synergy index between the UV and US+EC processes was determined

365 to be $20 \%$. The hybrid US+UV+EC procedure demonstrated that it could be utilized to completely

366 remove contaminants from industrial wastewater.

367 Ethics approval and consent to participate

368 Not applicable.

369 Consent for publication

370 Not applicable.

371 Authors Contributions

372 Perumal Asaithambi: Investigation; Data curation; Resources; Writing - original draft.

373 Rajendran Govindarajan: Investigation; Methodology; Data curation; Formal analysis; Resources.

374 Funding:

375 This research did not receive any specific grant from funding agencies in the public, commercial,

376 or not-for-profit sectors.

377 Availability of data and materials

378 The datasets analyzed during the study are available from the corresponding author on request.

379 Competing interests

380 The authors declare that they have no competing interests.

381 Reference

382 Ahlawat R, Srivastava VC, Mall ID, Sinha S (2008) Investigation of the Electrocoagulation 383 Treatment of Cotton Blue Dye Solution using Aluminium Electrodes. CLEAN - Soil, Air, 384 Water 36:863-869. https://doi.org/https://doi.org/10.1002/clen.200800019

385 Akansha J, Nidheesh P V, Gopinath A, et al (2020) Treatment of dairy industry wastewater by 386 combined aerated electrocoagulation and phytoremediation process. Chemosphere 
Al-Qodah Z, Tawalbeh M, Al-Shannag M, et al (2020) Combined electrocoagulation processes as a novel approach for enhanced pollutants removal: A state-of-the-art review. Sci Total Environ 744:. https://doi.org/10.1016/j.scitotenv.2020.140806

Alimohammadi M, Mesdaghinia A, Shayesteh MH, et al (2019) The efficiency of the electrocoagulation process in reducing fluoride: application of inductive alternating current and polarity inverter. Int $\mathrm{J}$ Environ Sci Technol 16:8239-8254. https://doi.org/10.1007/s13762-019-02297-4

Asaithambi P, Sajjadi B, Abdul Aziz AR, Wan Daud WMAB (2016) Performance evaluation of hybrid electrocoagulation process parameters for the treatment of distillery industrial effluent. Process Saf Environ Prot 104:406-412. https://doi.org/10.1016/j.psep.2016.09.023

Asaithambi P, Susree M, Saravanathamizhan R, Matheswaran M (2012) Ozone assisted electrocoagulation for the treatment of distillery effluent. Desalination 297:1-7. https://doi.org/10.1016/j.desal.2012.04.011

Aziz ARA, Asaithambi P, Daud WMABW (2016) Combination of electrocoagulation with advanced oxidation processes for the treatment of distillery industrial effluent. Process Saf Environ Prot 99:227-235. https://doi.org/10.1016/j.psep.2015.11.010

Chanikya P, Nidheesh P V., Syam Babu D, et al (2021) Treatment of dyeing wastewater by combined sulfate radical based electrochemical advanced oxidation and electrocoagulation processes. Sep Purif Technol 254:. https://doi.org/10.1016/j.seppur.2020.117570

Chen M, Dollar O, Shafer-Peltier K, et al (2020) Boron removal by electrocoagulation: Removal mechanism, adsorption models and factors influencing removal. Water Res 170:115362. https://doi.org/https://doi.org/10.1016/j.watres.2019.115362 
Chezeau B, Boudriche L, Vial C, Boudjemaa A (2020) Treatment of dairy wastewater by electrocoagulation process: Advantages of combined iron/aluminum electrodes. Sep Sci Technol 55:2510-2527. https://doi.org/10.1080/01496395.2019.1638935

Cotillas S, Llanos J, Miranda OG, et al (2014) Coupling UV irradiation and electrocoagulation for reclamation of urban wastewater. Electrochim Acta 140:396-403. https://doi.org/https://doi.org/10.1016/j.electacta.2014.04.037

Cotillas S, Llanos J, Moraleda I, et al (2020) Scaling-up an integrated electrodisinfectionelectrocoagulation process for wastewater reclamation. Chem Eng J 380:122415. https://doi.org/https://doi.org/10.1016/j.cej.2019.122415

da Costa PRF, de A. Costa ECT, Castro SSL, et al (2019) A sequential process to treat a cashewnut effluent: Electrocoagulation plus electrochemical oxidation. J Electroanal Chem 834:7985. https://doi.org/https://doi.org/10.1016/j.jelechem.2018.12.035

Dalvand A, Gholami M, Joneidi A, Mahmoodi NM (2011) Dye Removal, Energy Consumption and Operating Cost of Electrocoagulation of Textile Wastewater as a Clean Process. Clean Soil, Air, Water 39:665-672. https://doi.org/10.1002/clen.201000233

Das PP, Anweshan, Mondal P, et al (2021) Integrated ozonation assisted electrocoagulation process for the removal of cyanide from steel industry wastewater. Chemosphere 263:128370. https://doi.org/https://doi.org/10.1016/j.chemosphere.2020.128370

Deghles A, Kurt U (2016) Treatment of tannery wastewater by a hybrid electrocoagulation/electrodialysis process. Chem Eng Process Process Intensif 104:43-50. https://doi.org/10.1016/j.cep.2016.02.009

Dizge N, Akarsu C, Ozay Y, et al (2018) Sono-assisted electrocoagulation and cross-flow membrane processes for brewery wastewater treatment. J Water Process Eng 21:52-60. 
https://doi.org/10.1016/j.jwpe.2017.11.016

Emerick T, Vieira JL, Silveira MHL, João JJ (2020) Ultrasound-assisted electrocoagulation process applied to the treatment and reuse of swine slaughterhouse wastewater. J Environ Chem Eng 8:104308. https://doi.org/https://doi.org/10.1016/j.jece.2020.104308

Farhadi S, Aminzadeh B, Torabian A, et al (2012) Comparison of COD removal from pharmaceutical wastewater by electrocoagulation, photoelectrocoagulation, peroxielectrocoagulation and peroxi-photoelectrocoagulation processes. J Hazard Mater 219220:35-42. https://doi.org/https://doi.org/10.1016/j.jhazmat.2012.03.013

Gönder ZB, Balcıŏlu G, Vergili I, Kaya Y (2020) An integrated electrocoagulation-nanofiltration process for carwash wastewater reuse. Chemosphere 253:126713. https://doi.org/https://doi.org/10.1016/j.chemosphere.2020.126713

He CC, Hu CY, Lo SL (2016) Evaluation of sono-electrocoagulation for the removal of Reactive Blue 19 passive film removed by ultrasound. Sep Purif Technol 165:107-113. https://doi.org/10.1016/j.seppur.2016.03.047

He ZQ, Song S, Qiu JP, et al (2007) Decolorization of C.I. Reactive Yellow 84 in Aqueous Solution by Electrocoagulation Enhanced with Ozone: Influence of Operating Conditions. Environ Technol 28:1257-1263. https://doi.org/10.1080/09593332808618884

Igwegbe CA, Onukwuli OD, Ighalo JO, Umembamalu CJ (2021) Electrocoagulation-flocculation of aquaculture effluent using hybrid iron and aluminium electrodes: A comparative study. Chem Eng J Adv 6:100107. https://doi.org/https://doi.org/10.1016/j.ceja.2021.100107

Jallouli S, Wali A, Buonerba A, et al (2020) Efficient and sustainable treatment of tannery wastewater by a sequential electrocoagulation-UV photolytic process. J Water Process Eng 38:101642. https://doi.org/https://doi.org/10.1016/j.jwpe.2020.101642 
Keramati M, Ayati B (2019) Petroleum wastewater treatment using a combination of electrocoagulation and photocatalytic process with immobilized $\mathrm{ZnO}$ nanoparticles on $\begin{array}{lllll}\text { concrete } & \text { surface. } & \text { Process } & \text { Paf }\end{array}$ https://doi.org/10.1016/j.psep.2019.04.019

Li J, Song C, Su Y, et al (2013) A study on influential factors of high-phosphorus wastewater treated by electrocoagulation-ultrasound. Environ Sci Pollut Res 20:5397-5404. https://doi.org/10.1007/s11356-013-1537-9

Li Y-F, Hu C-Y, Lee Y-C, Lo S-L (2021) Effects of zinc salt addition on perfluorooctanoic acid (PFOA) removal by electrocoagulation with aluminum electrodes. Chemosphere 132665. https://doi.org/https://doi.org/10.1016/j.chemosphere.2021.132665

Maha Lakshmi P, Sivashanmugam P (2013) Treatment of oil tanning effluent by electrocoagulation: Influence of ultrasound and hybrid electrode on COD removal. Sep Purif Technol 116:378-384. https://doi.org/10.1016/j.seppur.2013.05.026

Mehralian M, Khashij M, Dalvand A (2021) Treatment of cardboard factory wastewater using ozone-assisted electrocoagulation process: optimization through response surface methodology. Environ Sci Pollut Res 28:45041-45049. https://doi.org/10.1007/s11356-021$13921-7$

Moradi M, Moussavi G (2019) Enhanced treatment of tannery wastewater using the electrocoagulation process combined with UVC/VUV photoreactor: Parametric and mechanistic evaluation. Chem Eng J 358:1038-1046. https://doi.org/https://doi.org/10.1016/j.cej.2018.10.069

Moradi M, Vasseghian Y, Arabzade H, Mousavi Khaneghah A (2021) Various wastewaters treatment by sono-electrocoagulation process: A comprehensive review of operational 
parameters and future outlook. Chemosphere

$263: 128314$. https://doi.org/10.1016/j.chemosphere.2020.128314

481

482

483

484

485

486

487

488

489

490

491

492

493

494

495

496

497

498

499

500

501

Moussavi M, Pendashteh A, Alinia H (2021) Treatment of a natural gas refinery effluents by $\begin{array}{lll}\text { electrocoagulation. } & \text { Environ } & \text { Challenges }\end{array}$ https://doi.org/https://doi.org/10.1016/j.envc.2021.100036

Nawarkar CJ, Salkar VD (2019) Solar powered Electrocoagulation system for municipal wastewater treatment. Fuel $237: 222-226$. https://doi.org/https://doi.org/10.1016/j.fuel.2018.09.140

Negarestani M, Motamedi M, Kashtiaray A, et al (2020) Simultaneous removal of acetaminophen and ibuprofen from underground water by an electrocoagulation unit: Operational parameters and kinetics. Groundw Sustain 11:100474. https://doi.org/https://doi.org/10.1016/j.gsd.2020.100474

Nigri EM, Santos ALA, Rocha SDF (2020) Removal of organic compounds, calcium and strontium from petroleum industry effluent by simultaneous electrocoagulation and $\begin{array}{lllll}\text { adsorption. } & \mathrm{J} & \text { Water } & \text { Process } & \text { Eng }\end{array}$ https://doi.org/https://doi.org/10.1016/j.jwpe.2020.101442

Oza H, Anantha Singh TS, Sasikumar Jampa S (2021) Removal of arsenic from aqueous solution using combined ultrasonic and electrocoagulation process. Mater Today Proc 47:728-732. https://doi.org/https://doi.org/10.1016/j.matpr.2021.01.569

Özyonar F, Gökkuş Ö, Sabuni M (2020) Removal of disperse and reactive dyes from aqueous solutions using ultrasound-assisted electrocoagulation. Chemosphere 258:127325. https://doi.org/https://doi.org/10.1016/j.chemosphere.2020.127325

Payami Shabestar M, Alavi Moghaddam MR, Karamati-Niaragh E (2021) Evaluation of energy 
and electrode consumption of Acid Red 18 removal using electrocoagulation process through RSM: alternating and direct current. Environ Sci Pollut Res. https://doi.org/10.1007/s11356021-15345-9

505 506

Prajapati AK (2021) Sono-assisted electrocoagulation treatment of rice grain based distillery biodigester effluent: Performance and cost analysis. Process Saf Environ Prot 150:314-322. https://doi.org/https://doi.org/10.1016/j.psep.2021.04.030

Preethi V, Ramesh ST, Gandhimathi R, Nidheesh PV (2020) Optimization of batch electrocoagulation process using Box-Behnken experimental design for the treatment of crude vegetable oil refinery wastewater. J Dispers Sci Technol 41:592-599. https://doi.org/10.1080/01932691.2019.1595640

Raschitor A, Fernandez CM, Cretescu I, et al (2014) Sono-electrocoagulation of wastewater polluted with Rhodamine 6G. Sep Purif Technol 135:110-116. https://doi.org/10.1016/j.seppur.2014.08.003

Romani M, Espinoza-Quiñones FR, Módenes AN, Borba CE (2020) New insights into the improvement of electrocoagulation performance on the basis of a time-integrated performance index: The pivotal role of electrical conductivity. J Environ Chem Eng 8:103902. https://doi.org/https://doi.org/10.1016/j.jece.2020.103902

Sandhwar VK, Prasad B (2018) Comparison of electrocoagulation, peroxi-electrocoagulation and peroxi-coagulation processes for treatment of simulated purified terephthalic acid wastewater: Optimization, sludge and kinetic analysis. Korean J Chem Eng 35:909-921. https://doi.org/10.1007/s11814-017-0336-2

Tavangar T, Jalali K, Alaei Shahmirzadi MA, Karimi M (2019) Toward real textile wastewater treatment: Membrane fouling control and effective fractionation of dyes/inorganic salts using 
541

542

543

544

545

546

547

47

Ucevli O, Kaya Y (2021) A comparative study of membrane filtration, electrocoagulation, chemical coagulation and their hybrid processes for greywater treatment. J Environ Chem Eng 9:104946. https://doi.org/https://doi.org/10.1016/j.jece.2020.104946

Valero P, Verbel M, Silva-Agredo J, et al (2017) Electrochemical advanced oxidation processes for Staphylococcus aureus disinfection in municipal WWTP effluents. J Environ Manage 198:256-265. https://doi.org/https://doi.org/10.1016/j.jenvman.2017.04.070

Zazou H, Afanga H, Akhouairi S, et al (2019) Treatment of textile industry wastewater by electrocoagulation coupled with electrochemical advanced oxidation process. J Water Process Eng 28:214-221. https://doi.org/https://doi.org/10.1016/j.jwpe.2019.02.006

6

7

8

9

0

41

42

43

46




\section{List of Figures}

549

550

551

552

553

554

Fig. 1. (a), (b) \& (c). Experimental setup of EC, US+EC \& hybrid US+UV+EC process.

Fig. 2. Effect of treatment time on COD removal and EEC by hybrid US+UV+EC process (current density $=0.175 \mathrm{~A} \mathrm{dm}^{-2}, \mathrm{COD}=3600 \mathrm{mg} \mathrm{L}^{-1}, \mathrm{UV}=32 \mathrm{~W}, \mathrm{US}=100 \mathrm{~W}$, electrode combination $=$ $\mathrm{Fe} / \mathrm{Fe}$, inter-electrode distance $=0.75 \mathrm{~cm}$ and $\mathrm{pH}=7)$.

Fig. 3. Effect of current density on EEC and COD removal by hybrid US+UV+EC process (COD $=3600 \mathrm{mg} \mathrm{L}^{-1}, \mathrm{UV}=32 \mathrm{~W}, \mathrm{US}=100 \mathrm{~W}$, electrode combination $=\mathrm{Fe} / \mathrm{Fe}$, inter-electrode distance $=0.75 \mathrm{~cm}, \mathrm{pH}=7$, and reaction time $=4 \mathrm{~h})$.

Fig. 4. Effect of COD concentration on EEC and COD removal by hybrid US+UV+EC process (current density $=0.175 \mathrm{~A} \mathrm{dm}^{-2}, \mathrm{UV}=32 \mathrm{~W}, \mathrm{US}=100 \mathrm{~W}$, electrode combination $=\mathrm{Fe} / \mathrm{Fe}$, inter electrode distance $=0.75 \mathrm{~cm}, \mathrm{pH}=7$, and reaction time $=4 \mathrm{~h}$ ).

Fig. 5. Effect of UV power on EEC and COD removal by hybrid US+UV+EC process (current density $=0.175 \mathrm{~A} \mathrm{dm}^{-2}, \mathrm{COD}=3600 \mathrm{mg} \mathrm{L}^{-1}, \mathrm{US}=100 \mathrm{~W}$, electrode combination $=\mathrm{Fe} / \mathrm{Fe}$, interelectrode distance $=0.75 \mathrm{~cm}, \mathrm{pH}=7$, and reaction time $=4 \mathrm{~h}$ ).

Fig. 6. Effect of US power on EEC and COD removal by hybrid US+UV+EC process (current density $=0.175 \mathrm{~A} \mathrm{dm}^{-2}, \mathrm{COD}=3600 \mathrm{mg} \mathrm{L}^{-1}, \mathrm{UV}=32 \mathrm{~W}$, electrode combination $=\mathrm{Fe} / \mathrm{Fe}$, inter electrode distance $=0.75 \mathrm{~cm}, \mathrm{pH}=7$, and reaction time $=4 \mathrm{~h}$ ).

Fig. 7. Effect of electrode combination on EEC and COD removal by hybrid US+UV+EC process (current density $=0.175 \mathrm{~A} \mathrm{dm}^{-2}, \mathrm{COD}=3600 \mathrm{mg} \mathrm{L}^{-1}, \mathrm{UV}=32 \mathrm{~W}, \mathrm{US}=100 \mathrm{~W}$, inter-electrode distance $=0.75 \mathrm{~cm}, \mathrm{pH}=7$, and reaction time $=4 \mathrm{~h}$ ).

Fig. 8. Effect of inter-electrode distance on EEC and COD removal by hybrid US+UV+EC process (current density $=0.175 \mathrm{~A} \mathrm{dm}^{-2}, \mathrm{COD}=3600 \mathrm{mg} \mathrm{L}^{-1}, \mathrm{UV}=32 \mathrm{~W}, \mathrm{US}=100 \mathrm{~W}$, electrode combination $=\mathrm{Fe} / \mathrm{Fe}, \mathrm{pH}=7$, and reaction time $=4 \mathrm{~h}$ ). 
571 Fig. 9. Comparison of UV only, US only, EC only, UV+US, UV+EC, US+EC and US+UV+EC

572 process on the (a) color, (\%) and COD removal, (\%) and (b) EEC from distillery wastewater

573 (current density $=0.175 \mathrm{~A} \mathrm{dm}^{-2}, \mathrm{COD}=3600 \mathrm{mg} \mathrm{L}^{-1}, \mathrm{UV}=32 \mathrm{~W}, \mathrm{US}=100 \mathrm{~W}$, electrode

574 combination $=\mathrm{Fe} / \mathrm{Fe}$, inter-electrode distance $=0.75 \mathrm{~cm}, \mathrm{pH}=7$, and reaction time $=4 \mathrm{~h}$ ).

575

576

577

578

579

580

581

582

583

584 


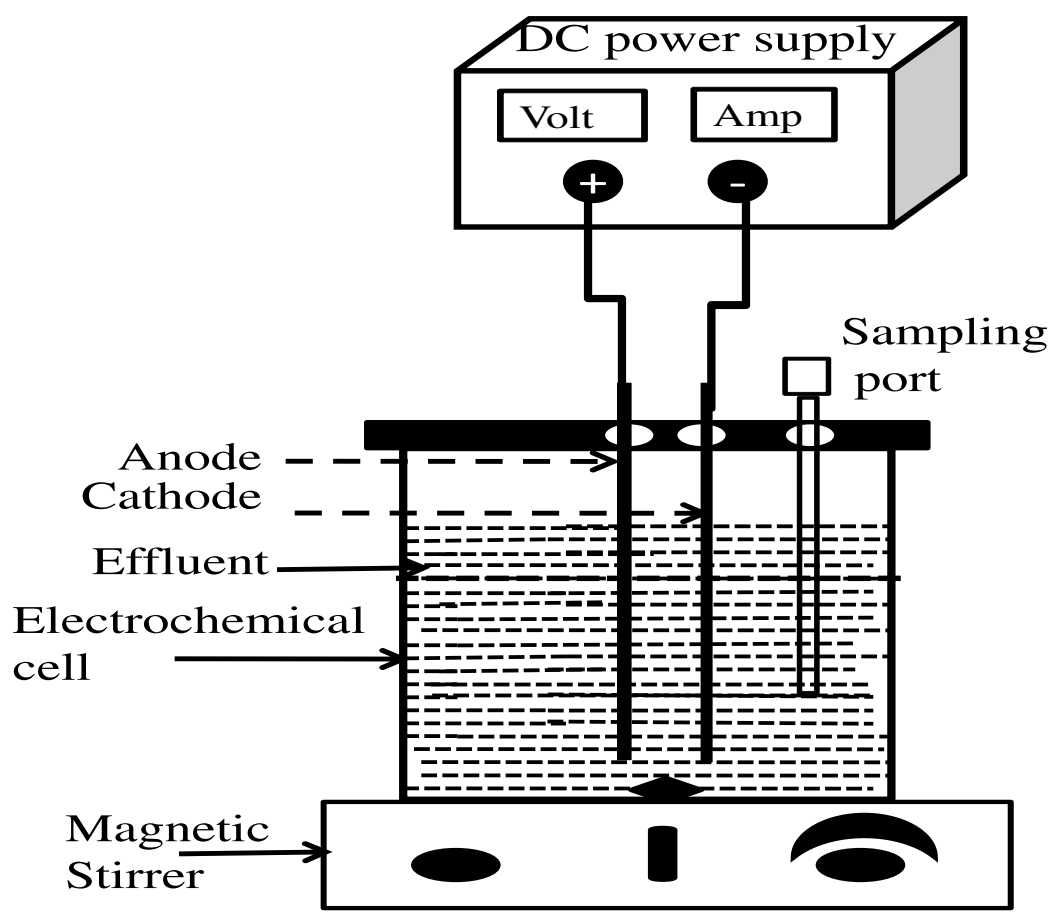

595

Fig. 1. (a)

596

597

598

599

600

601

602

603

604

605

606

607

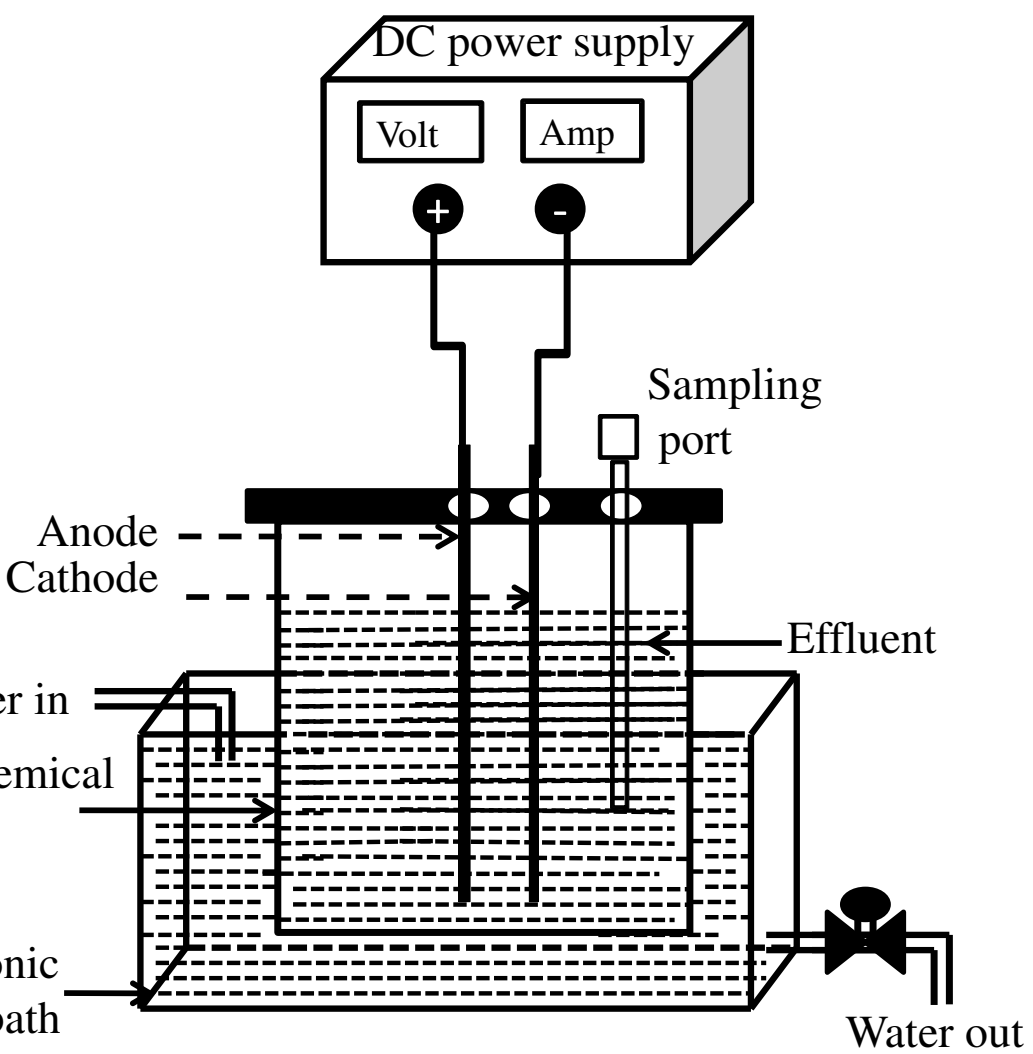

608

Fig. 1. (b) 


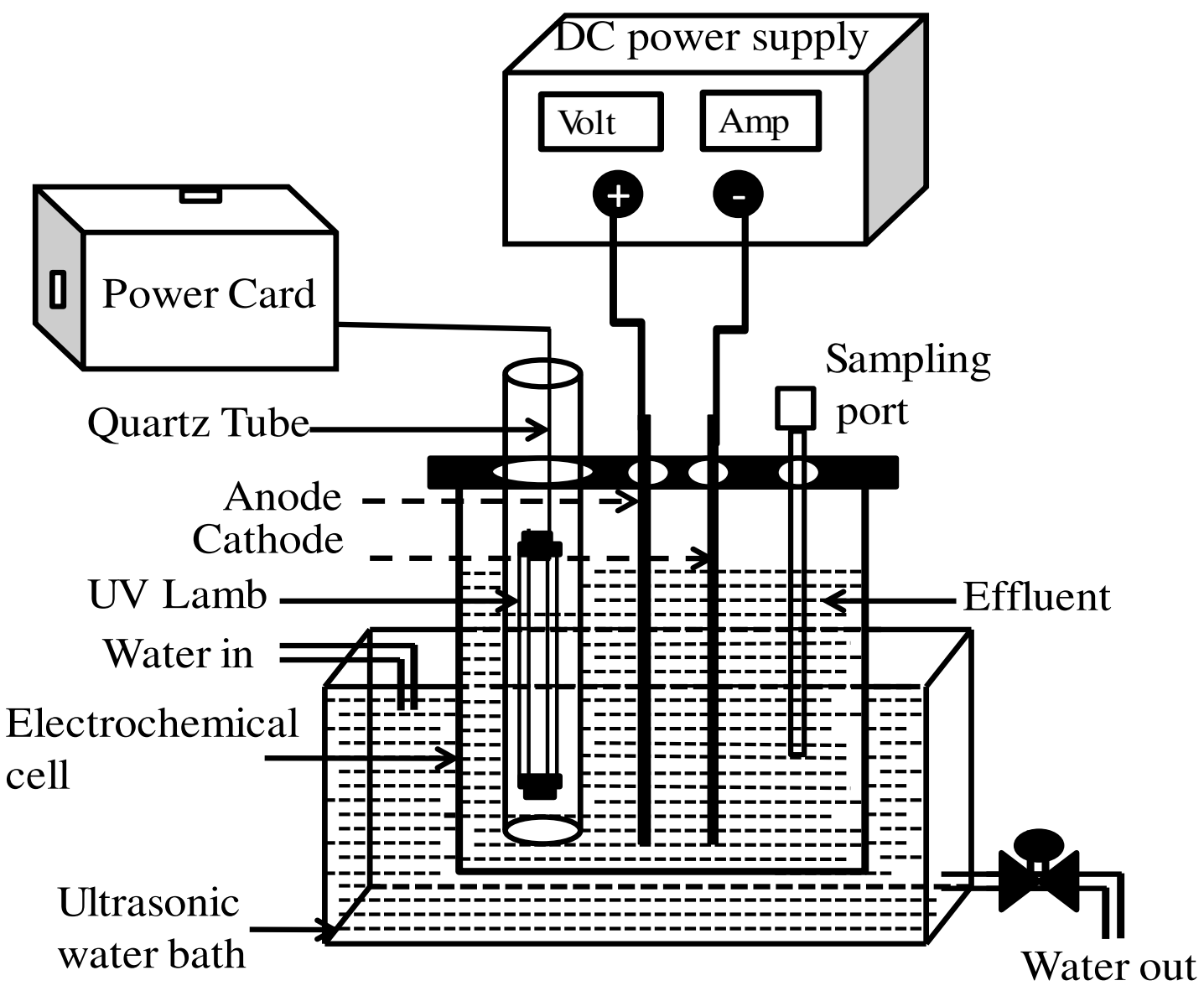

625

Fig. 1. (c)

626

627

628

629

630

631

632

633 


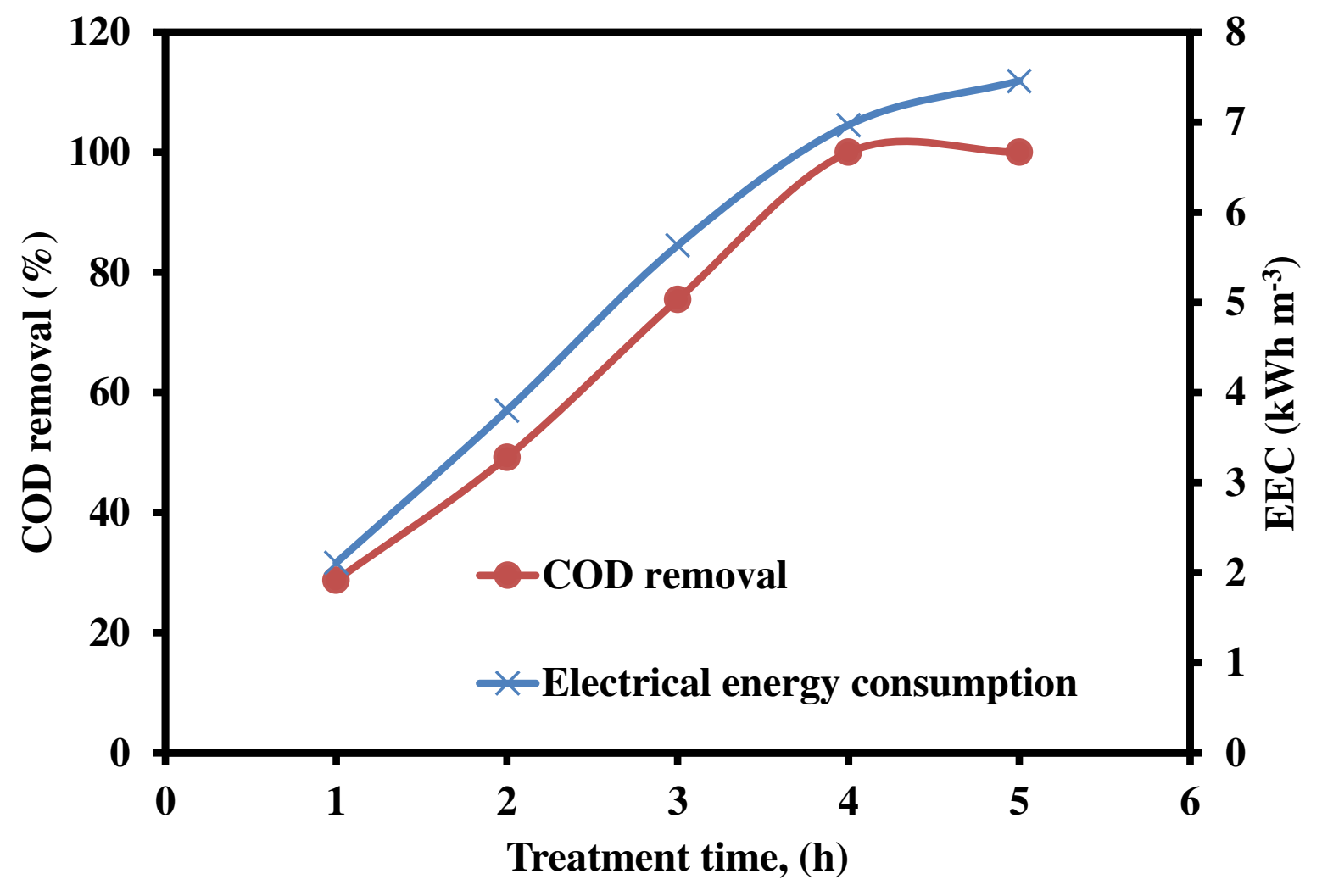




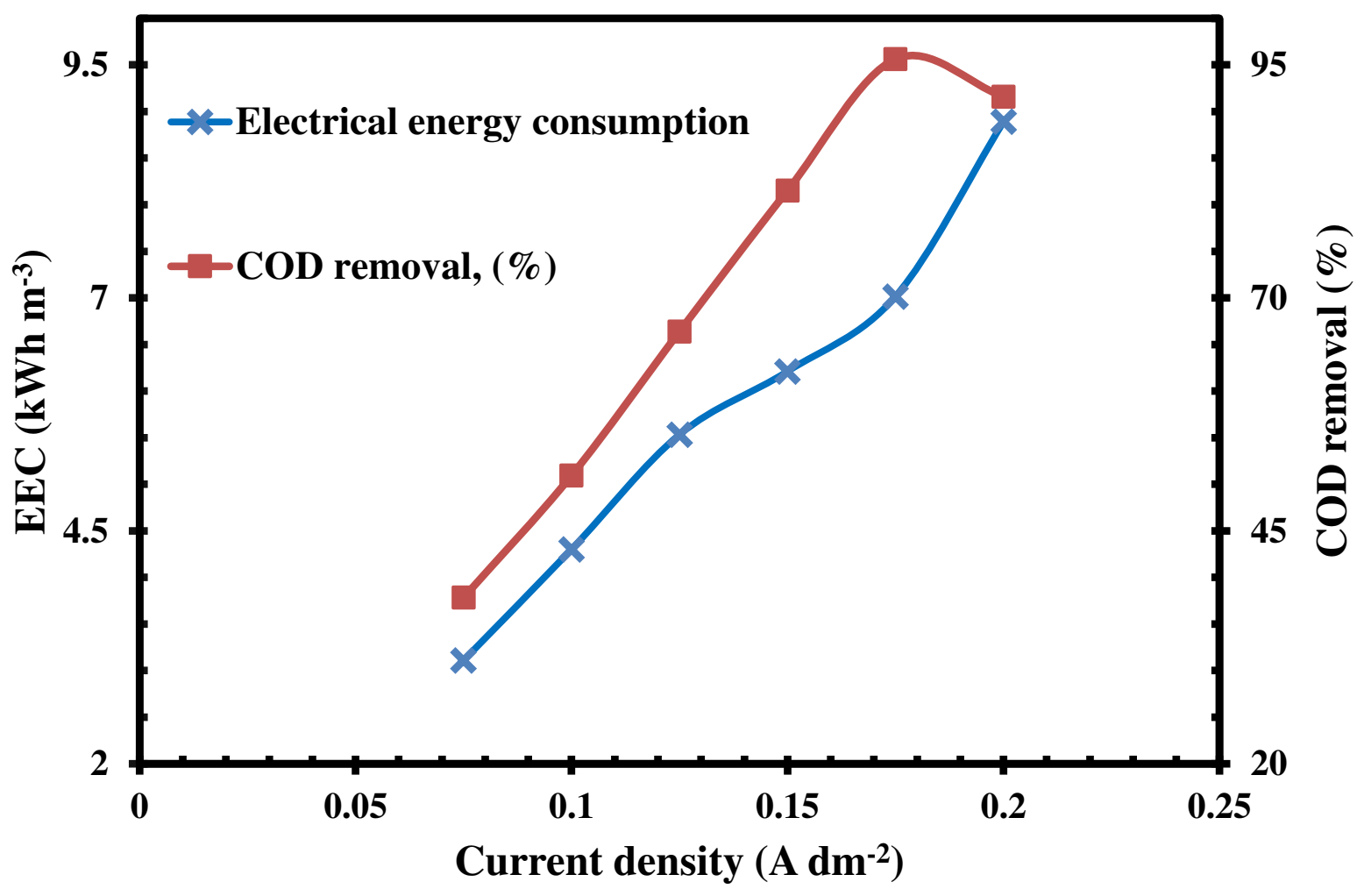

650

Fig. 3 


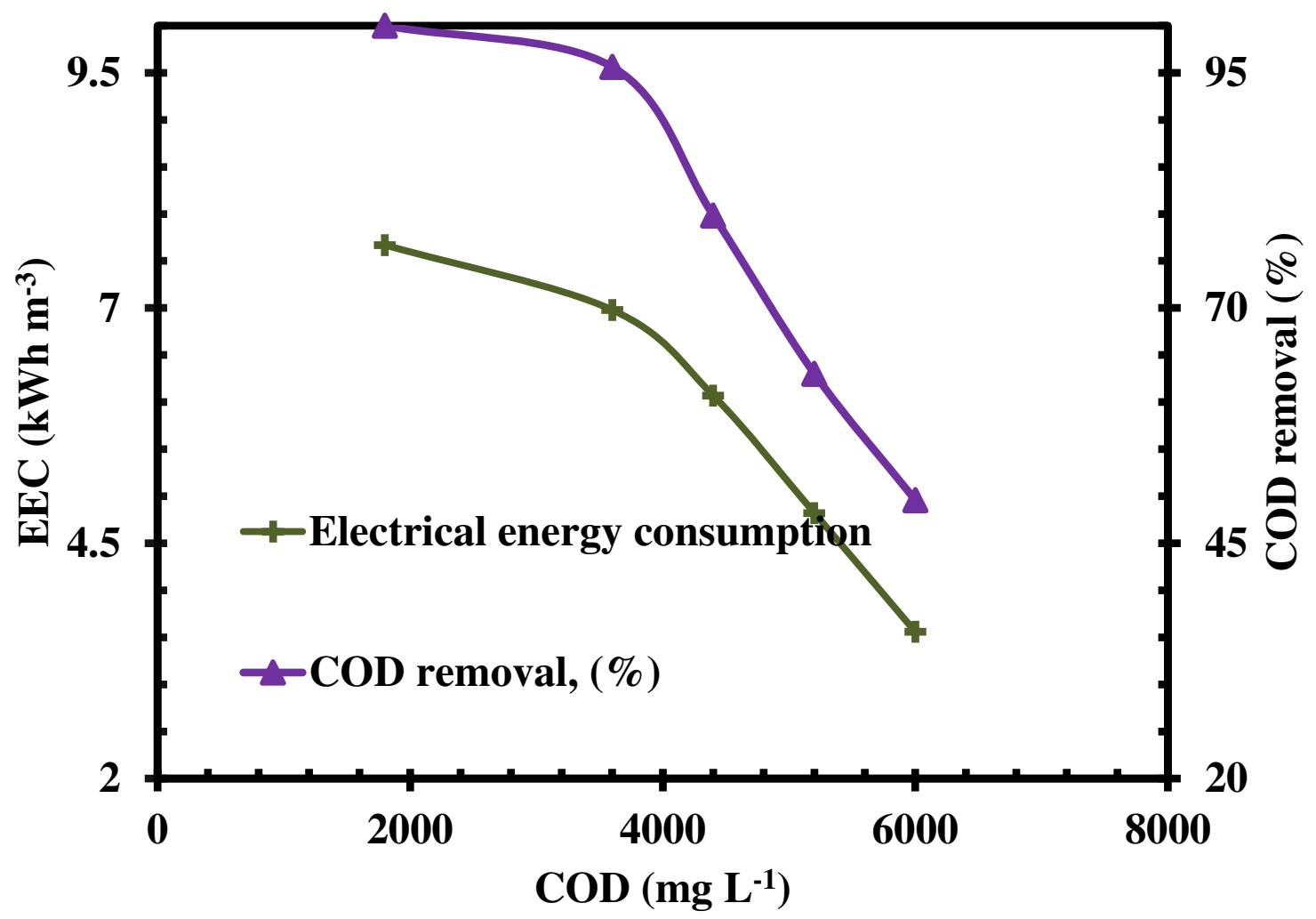


674

675

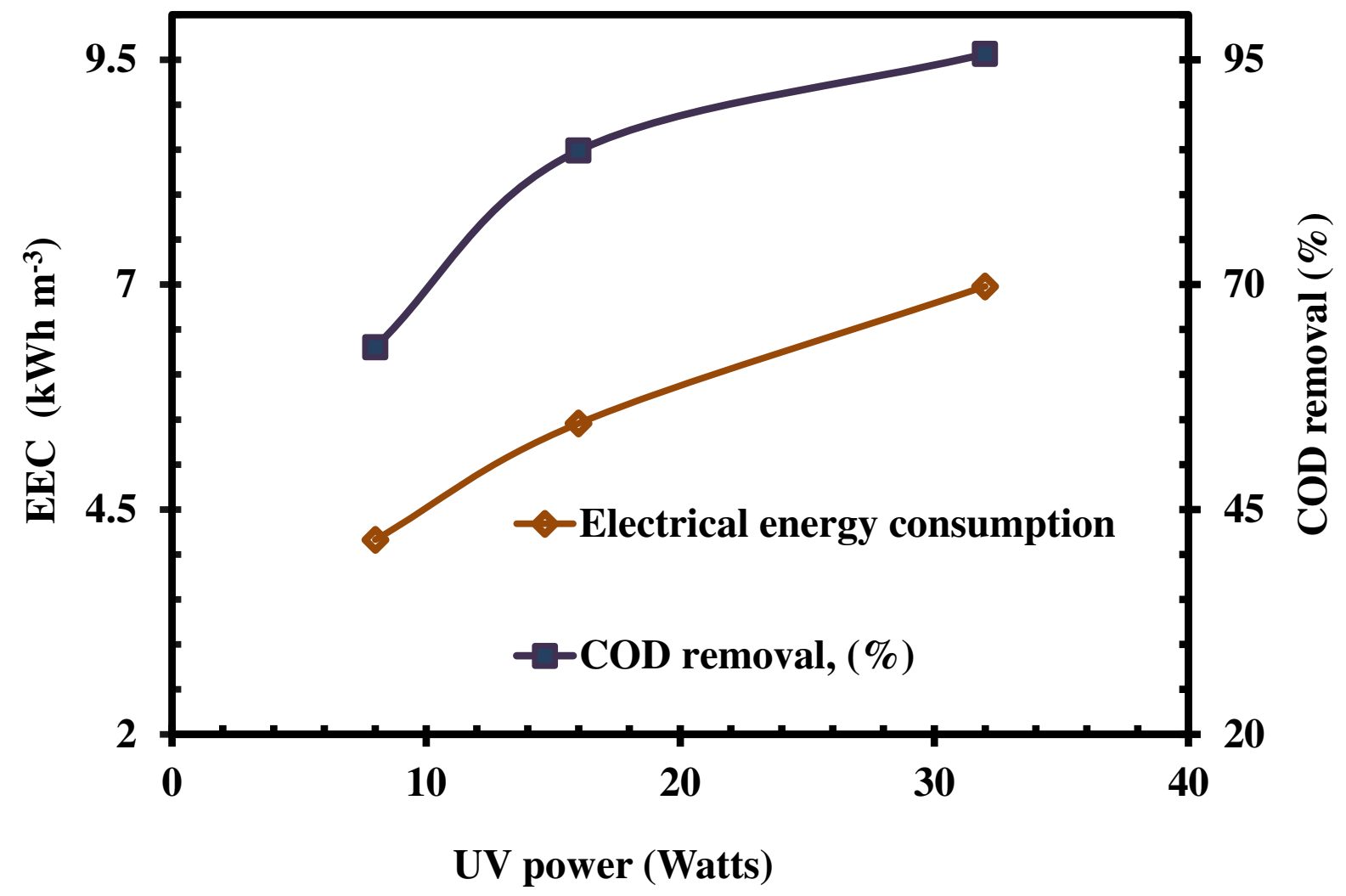




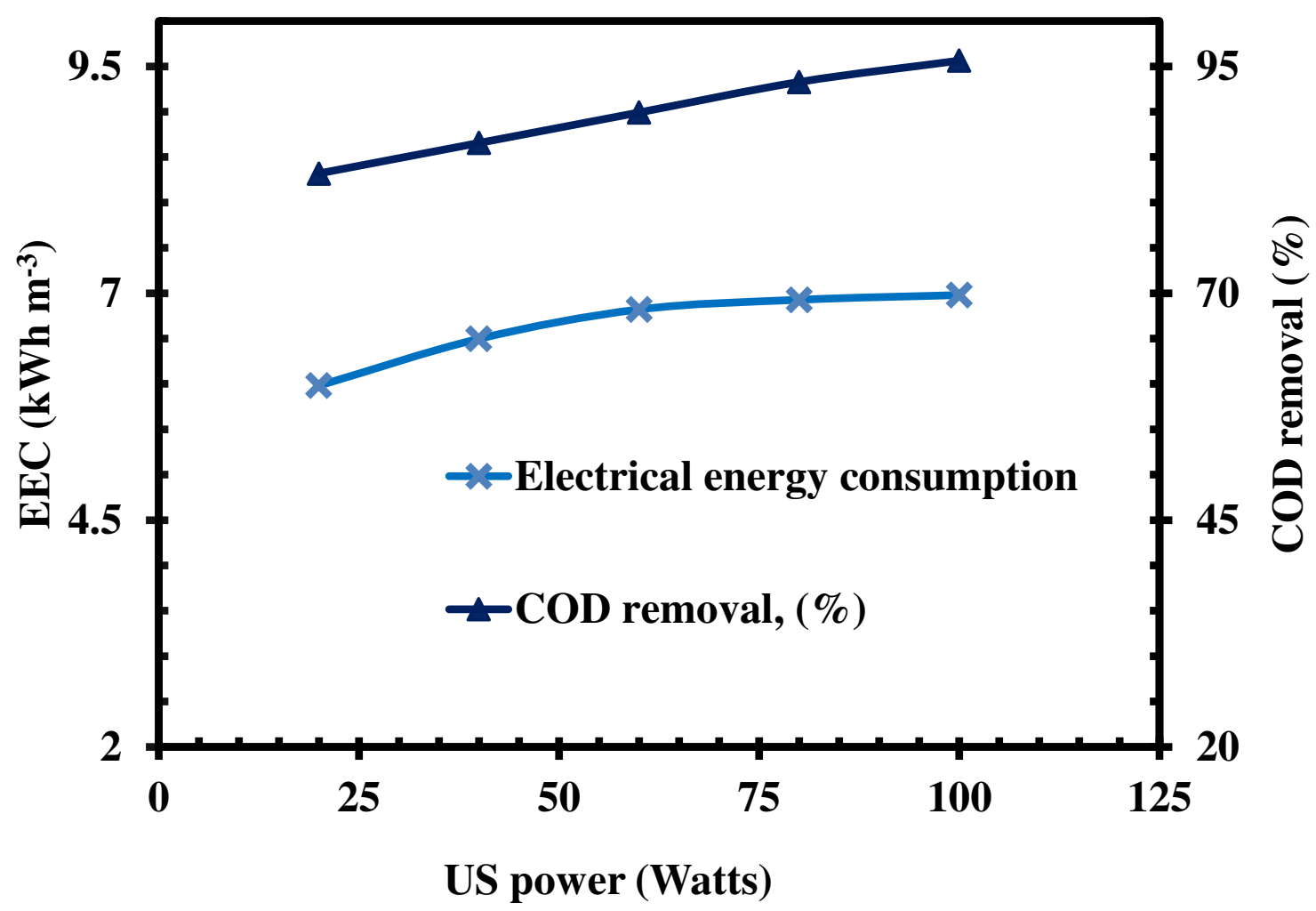

700

Fig. 6

702 


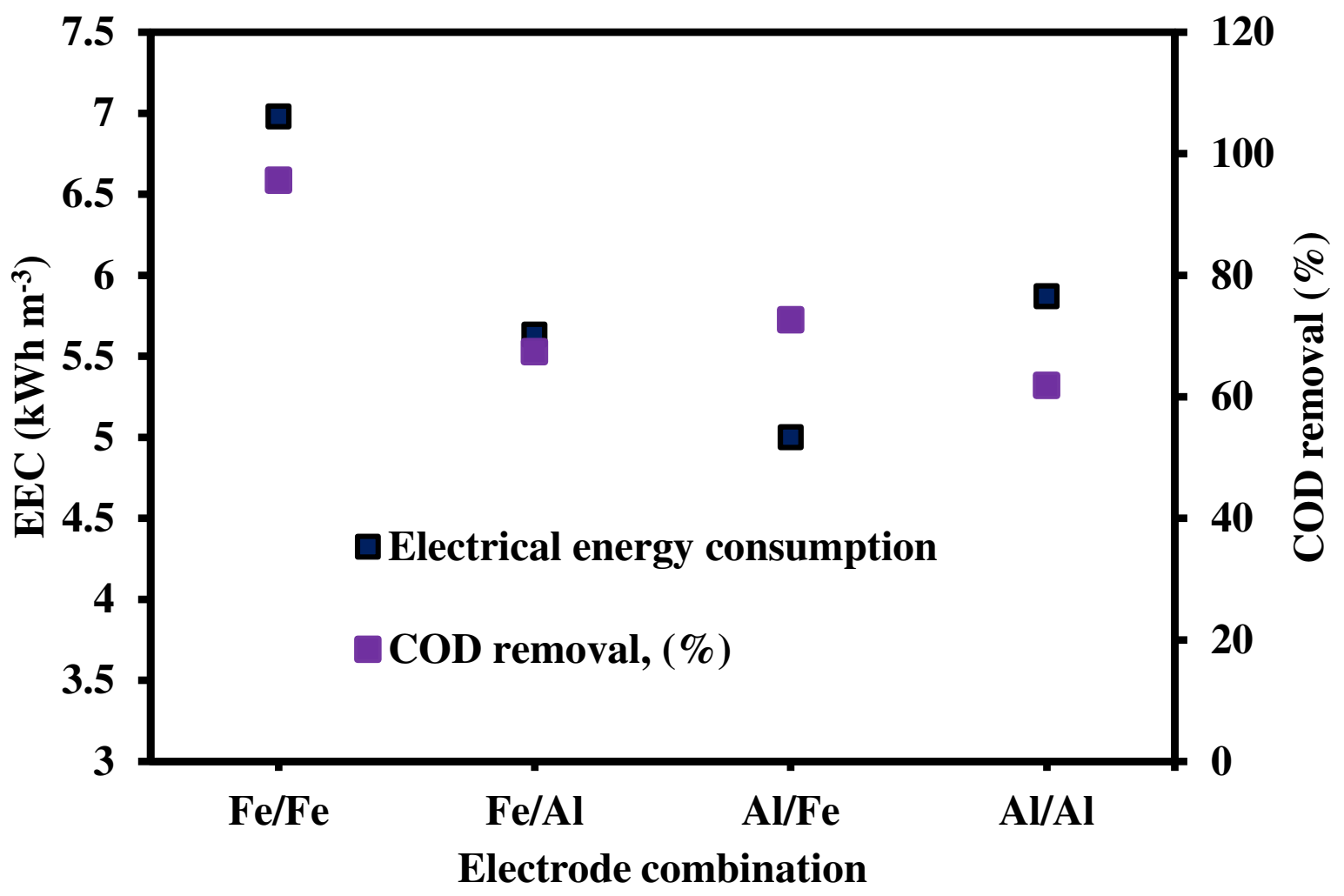




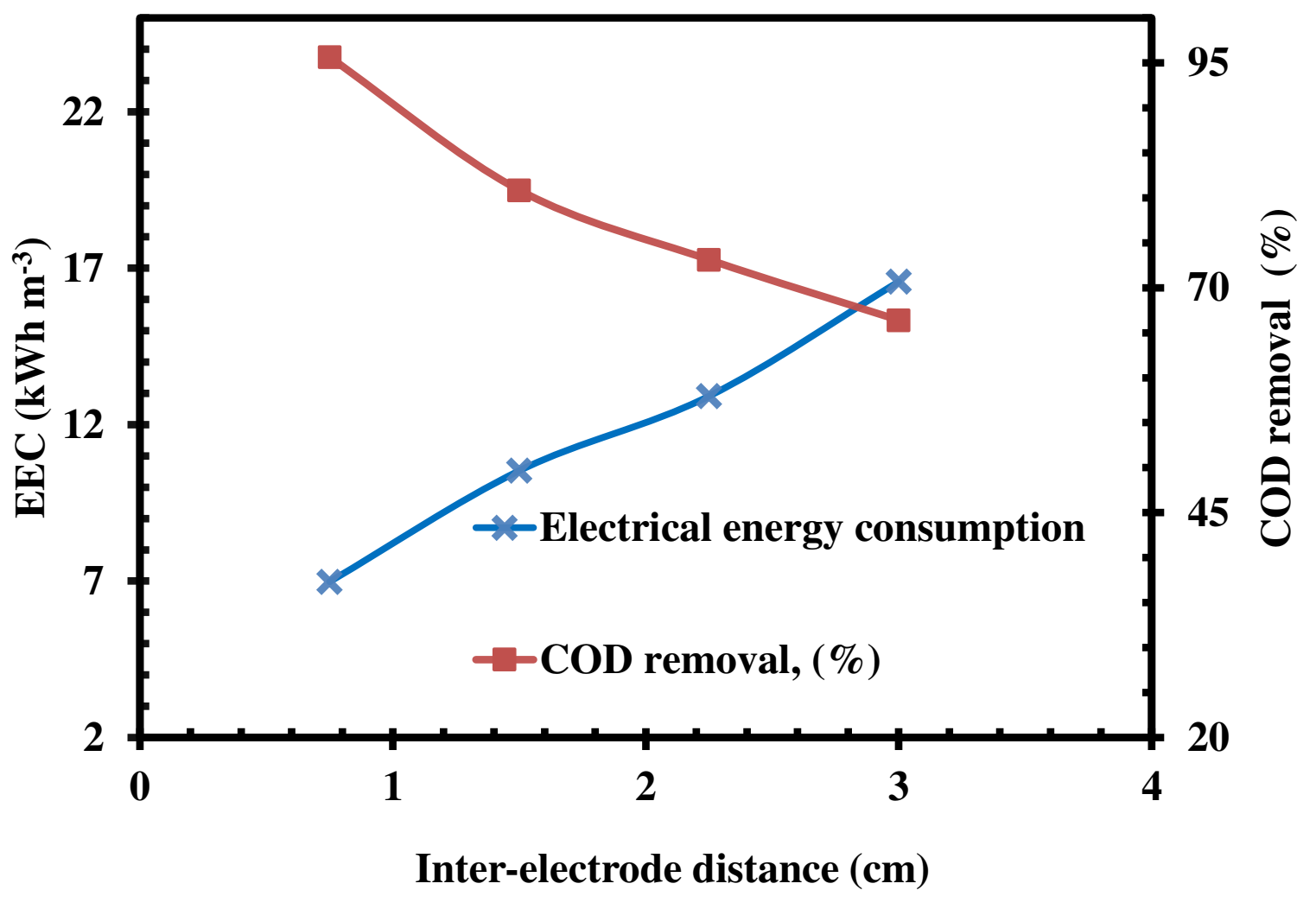

Fig. 8 


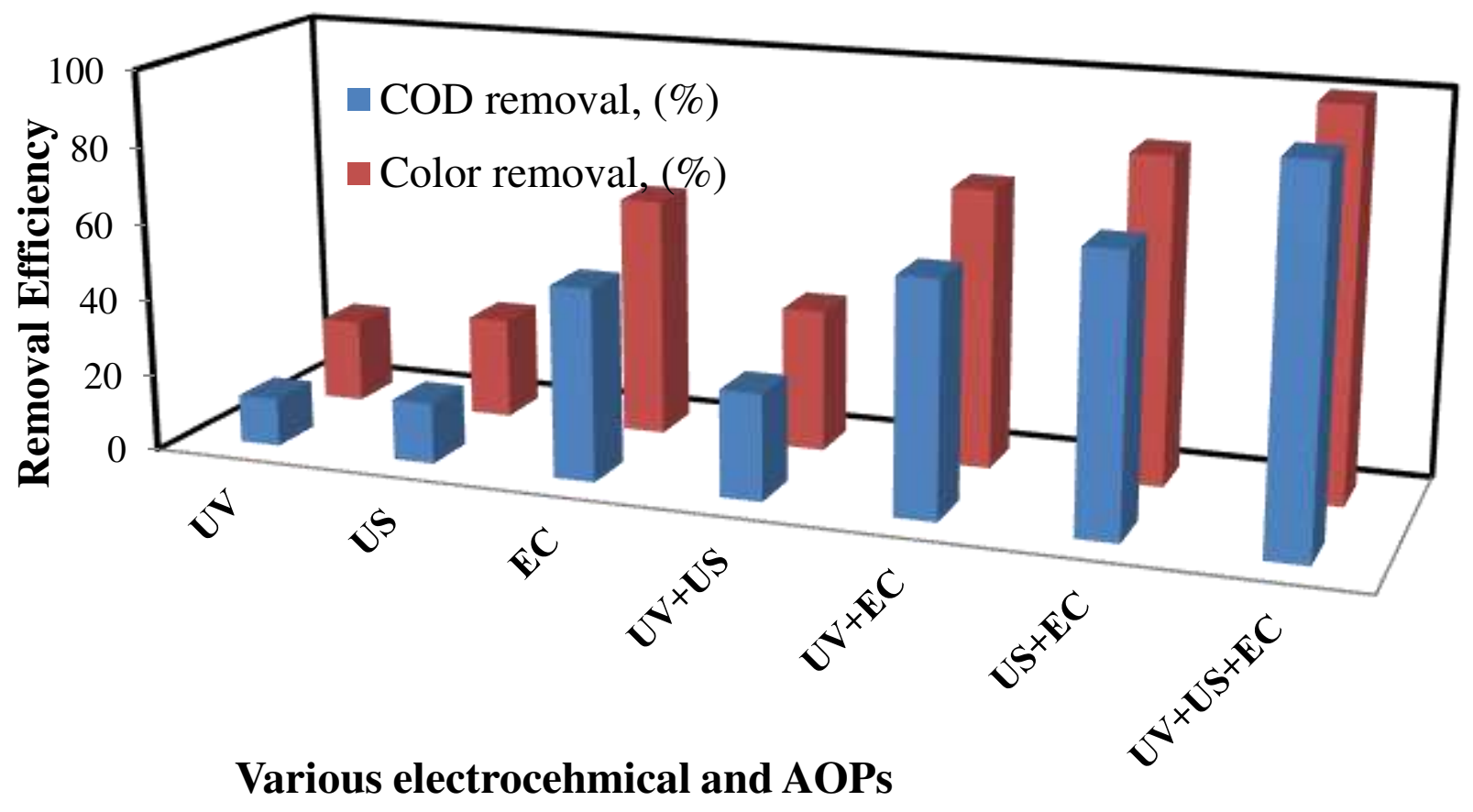

$725 \quad$ (a)

726

727

728

729

730

731

732

733

734

735

(b)

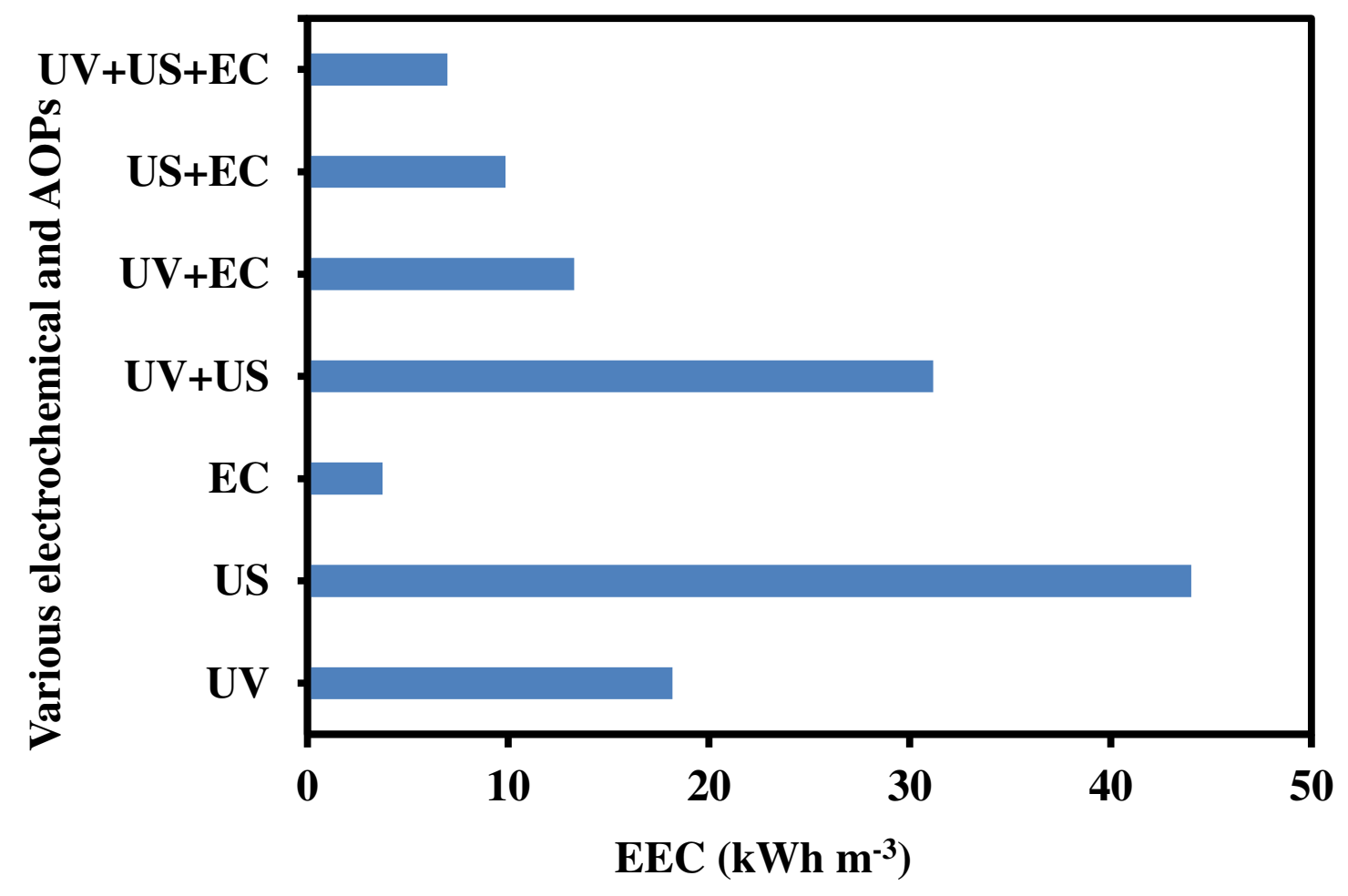

736

Fig. 9 